\title{
Pengaruh Gaya Kepemimpinan dan Insentif terhadap Motivasi Serta Dampaknya terhadap Kinerja Pegawai Dinas Peternakan dan Perikanan Kabupaten Bungo
}

\author{
M. Alhudhori, Evi Adriani, M. Zahari MS, Albetris \\ Fakultas Ekonomi Universitas Batanghari Jambi, Indonesia \\ Jl. Slamet Ryadi, Broni, Kecamatan Telanaipura Kota Jambi \\ Correspondence email: alhudhori811@gmail.com
}

\begin{abstract}
The performance of organization can be seen to the extent of work productivity has been produced. Generally, productivity is defined as the influence between real and physical results with actual input. This study discusses the influence of leadership style and intensive on motivation and its impact on performance in the Bungo District Livestock and Fisheries Office. Data were obtained using questionnaire and literature review methods, with 54 respondents. Then the data were analyzed using descriptive and statistical methods through path analysis. This study resulted in a leadership style, incentives, motivation and performance of the Bungo District Animal Husbandry and Fisheries Office, both for the leadership style with a score of 1930, for incentives with a score of 1438, for motivation with a score of 804 and performance at a score of 2342 in the very high category. Leadership style towards the motivation of the Bungo Regency Animal Husbandry and Fisheries Office has a direct or indirect influence with a value of $20.35 \%$. The incentives for the motivation of the Bungo Regency Animal Husbandry and Fisheries Office have a direct or indirect influence with a value of $0.205 \%$. The leadership style and incentives for the motivation of the Bungo Regency Animal Husbandry and Fisheries Office have a direct or indirect influence with a value of $2.86 \%$. There is an influence of leadership style on the performance of the Bungo Regency Animal Husbandry and Fisheries Office with a value of $1.43 \%$. There is an incentive effect on the performance of the Bungo Regency Animal Husbandry and Fisheries Office with a value of 2.65\%. The leadership style and incentives for the performance of the Bungo Regency Animal Husbandry and Fisheries Office have an influence of $2.471 \%$. The influence of motivation on the performance of the Bungo District Animal Husbandry and Fisheries Office is at 4.057\%. Leadership styles and incentives through motivation on the performance of the Bungo District Animal Husbandry and Fisheries Office have an effect of 1.478\%.
\end{abstract}

Keywords: Leadership Style; incentives; motivation; performance

\section{PENDAHULUAN}

Manajemen merupakan bagian proses jalannya suatu organisasi, dimana di dalamnya terjadi kegiatan pengaturan staf, waktu, sarana dan prasarana, keuangan dan metode. Menurut Griffin (2007) Manajemen sebagai sebuah proses perencanaan, pengorganisasian, pengkoordinasian, dan pengontrolan sumber daya untuk mencapai sasaran (goals) secara efektif dan efesien. Efektif berarti bahwa tujuan dapat dicapai sesuai dengan perencanaan, sementara efisien berarti bahwa tugas yang ada dilaksanakan secara benar, terorganisir, dan sesuai dengan jadwal.

Sasaran dari proses manajamen adalah kinerja, artinya kelakuan atau kegiatan yang berhubungan dengan organisasi, di mana organisasi tersebut merupakan keputusan dari pimpinan. Dikatakan bahwa kinerja bukan outcome, konsekuensi atau hasil dari perilaku atau perbuatan, tetapi kinerja adalah perbuatan atau aksi itu sendiri, di samping itu kinerja adalah multidimensi sehingga untuk beberapa pekerjaan yang spesifik mempunyai beberapa bentuk komponen kinerja yang dibuat dalam batas hubungan variasi dengan variabel- variabel lain (Mc Cloy etal, 1994)

Simanjuntak (2011) mengungkapkan bahwa kinerja suatu organisasi dapat diukur dengan, pertama, sasaran atau target sebagaimana yang telah dirumuskan atau dinyatakan di dalam rencana kerja, Kedua, standar umum, baik yang ditetapkan sebagai ketentuan atau pedoman oleh instansi resmi maupun yang diterima secara konsensus di tingkat nasional atau internasional, Ketiga, standar yang telah ditetapkan secara khsusus misalnya dalam menerima kerja kontrak, Keempat, uraian tugas atau uraian jabatan menggambarkan pekerjaan atau tugas yang harus dilaksnakan oleh pejabat yang bersangkutan. Kelima, misi atau tugas pokok organisasi atau unit organisasi menggambarkan apa yang harus dicapai oleh oragnisasi tersebut dalam kurun waktu tertentu (hal. 118)

Selanjutnya, Simanjuntak mengungkapkan bahwa kinerja setiap orang dipengaruhi oleh banyaknya faktor di antaranya yaitu: (1) kompetensi individu yang bersangkutan; (2) dukungan organisasi dan (3) 
dukungan manajemen (hal. 120). Lebih lanjut dijelaskan bahwa semakin banyak macam pekerjaan yang dilakukan seseorang, pengalaman kerjanya semakin kaya, luas, dan memungkinkan peningkatan kinerja.

Selain itu, Sinungan (2005) menerangkan bahwa kinerja suatu organisasi dapat dilihat dari sejauhmana produktivitas kerja yang telah dihasilkan. Secara umum, produktivitas diartikan sebagai pengaruh antara hasil nyata maupun fisik (barang-barang dan jasa) dengan masukan yang sebenarnya. Produktivitas adalah ukuran efisiensi produktif. Suatu perbandingan antara hasil keluaran dan masukan atau output: input. Masukan sering dibatasi dengan masukan tenaga kerja, sedangkan keluaran diukur dalam kesatuan fisik bentuk dan nilai. Produktivitas juga diartikan sebagai tingkat efisiensi dalam memproduksi barang-barang atau jasa-jasa. Dimana produktifitas mengutarakann cara pemanfaatan secara baik terhadap sumber-sumber dalam memproduksi barang-barang.

Untuk mendapat produktivitas tersebut sangat dipengaruhi oleh seorang pemimpin. Gaya kepemimpinan dalam suatu organisasi salah satu faktor yang menentukan produktivitas dan kinerja organisasi. Wahyudi (2006) mengungkapkan bahwa gaya kepemimpinan seorang pemimpin akan mempengaruhi cara-cara berkomunikasi, budaya, pengambilan keputusan dan kepemimpinan dalam perusahaan. Oleh karena itu, seorang pemimpin harus mampu berusaha menyesuaikan gaya kepemimpinannya dengan kondisi dan tujuan organisasi.

Thoha (2003) mengungkapkan bahwa gaya kepemimpinan merupakan norma perilaku yang digunakan seseorang pada saat orang tersebut mencoba mempengaruhi orang lain seperti yang ia lihat.

Wahyudi menjelaskan bahwa gaya kepemimpinan juga dapat mempengaruhi budaya suatu organisasi. Robbins (2003) mengungkapkan bahwa budaya organisasi merupakan sistem makna bersama yang dianut oleh anggota- anggota yang membedakan suatu organisasi dari organisasi lain. Sistem makna bersama ini, bila diamati dengan lebih seksama, merupakan seperangkat karakteristik utama yang dihargai oleh suatu organisasi. Budaya organisasi berkaitan dengan bagaimana karyawan mempersepsikan karakteristik dari suatu budaya organisasi, bukan dengan apakah para karyawan menyukai budaya atau tidak. Selanjutnya Robbins ungkapkan bahwa budaya mempunyai suatu peran menetapkan tapal batas, yang artinya budaya menciptakan pembedaan yang jelas antara satu organisasi dengan organisasi yang lain.

Menurut Kerlinger dan Padhazur (2002) faktor kepemimpinan mempunyai peran yang sangat penting dalam meningkatkan kinerja pegawai karena kepemimpinan yang efektif memberikan pengarahan terhadap usaha-usaha semua pekerja dalam mencapai tujuan-tujuan organisasi. Gaya kepemimpinan yang efektif dibutuhkan pemimpin untuk dapat meningkatkan kinerja semua pegawai dalam mencapai tujuan organisasi sebagai instansi pelayanan publik. Dengan demikian, gaya kepemimpinan dapat menjadi pedoman yang baik dalam peningkatan kinerja pegawai

Oleh itu, seorang pemimpin perusahaan harus memperhatikan faktor- faktor seperti; bagaimana keadaan atau kondisi kerja seorang karyawan dalam memenuhi tuntutan kerja perusahaan, peraturanperaturan dalam perusahaan, sehingga tercipta kondisi demikian. Sebaliknya untuk menciptakan kinerja karyawan berkualitas tinggi memerlukan waktu relatif lama yang secara umum dipengaruhi oleh kemampuan dan tindakan perusahaan dalam memenuhi faktor- faktor kebutuhan dan keinginan yang diharapkan karyawan. Di sisi lain perlu diketahui bahwa tidak selamanya pemenuhan kebutuhan dan keinginan karyawan dapat mendorong kemampuan produktivitasnya. Sebab pada kondisi - kondisi tertentu kemampuan kerja seorang karyawan dapat menurun kendatipun kebutuhan dan keinginannya terpenuhi.

Selain gaya kepemimpinan, kinerja juga dipengaruhi oleh insentif karena insentif dapat mempengaruhi motivasi kerja karyawan. Handoko (2002:176), menyatakan bahwa pengertian insentif adalah :"Perangsang yang ditawarkan kepada para karyawan untuk melaksanakan kerja sesuai atau lebih tinggi dari standar-standar yang telah ditetapkan"

Insentif merupakan suatu penghargaan dalam bentuk material atau non material yang diberikan oleh pihak pimpinan organisasi perusahaan kepada karyawan agar mereka bekerja dengan motivasi yang tinggi dan berprestasi dalam mencapai tujuan-tujuan perusahaan, dengan kata lain pemberian insentif adalah pemberian uang diluar gaji sebagai pengakuan terhadap prestasi kerja dan kontribusi terhadap karyawan kepada perusahaan. Pelaksanaan insentif dimaksudkan untuk meningkatkan produktifitas karyawan dan mempertahankan karyawan yang berprestasi agar 
tetap berada dalam perusahaan. Insentif adalah dorongan agar seseorang agar mau bekerja dengan baik dan agar dapat mencapai produktivitas yang tinggi sehingga dapat membangkitkan gairah kerja dan motivasi yang tinggi.

Secara detil insentif yang diberikan kepada karyawan Dinas Peternakan dan Perikanan Bungo dapat diuraikan pada tabel 1 berikut.

Tabel 1.

Jenis dan besar Insentif

\begin{tabular}{llc}
\hline No & \multicolumn{1}{c}{ Nama Kegiatan } & Jumlah Insentif \\
\hline 1 & Insiminasi Buatan & 50.000 \\
2 & Singkronisasi & 30.000 \\
3 & Pemeriksaan Kebuntingan & 30.000 \\
4 & Kelahiran & 5000 \\
5 & Reproduksi dan Pengobatan & 125.000 \\
\hline
\end{tabular}

Sumber. Dinas Peternakan dan Peerikanan Kab. Bungo

\section{Tinjauan Pustaka \\ Gaya kepemimpinan}

Setiap pemimpin pada dasarnya memiliki perilaku yang berbeda dalam memimpin para pengikutnya, perilaku para pemimpin itu disebut dengan gaya kepemimpinan. Gaya kepemimpinan merupakan suatu cara pemimpin untuk mempengaruhi bawahannya yang dinyatakan dalam bentuk pola tingkah laku atau kepribadian. Seorang pemimpin merupakan seseorang yang memiliki suatu program dan yang berperilaku secara bersama-sama dengan anggota- anggota kelompok dengan mempergunakan cara atau gaya tertentu, sehingga kepemimpinan mempunyai peranan sebagai kekuatan dinamik yang mendorong, memotivasi dan mengkordinasikan perusahaan dalam mencapai tujuan yang telah ditetapkan.

Menurut Kartono (2008:34) Menyatakan sebagai berikut :Gaya kepemimpinan adalah sifat, kebiasaan, tempramen, watak dan kepribadian yang membedakan seorang pemimpin dalam berinteraksi dengan orang lain". Menurut Thoha (2010:49) mengemukakan bahwa "Gaya kepemimpinan merupakan norma prilaku yang digunakan oleh seseorang pada saat orang tersebut mencoba mempengaruhi prilaku orang lain atau bawahan".

Menurut Herujito (2006:188) menyatakan gaya kepemimpinan adalah sebagai berikut :"Gaya kepemimpinan bukan bakat, oleh karena itu gaya kepemimpinan dipelajari dan dipraktekan dalam penerapannya harus sesuai dengan situasi yang dihadapi”.

Sedangkan menurut Supardo (2006:4), menyatakan bahwa: "Gaya kepemimpinan adalah suatu cara dan porses kompleks dimana seseorang mempengaruhi orang-orang lain untuk mencapai suatu misi, tugas atau suatu sasaran dan mengarahkan organisasi dengan cara yang lebih masuk akal”.

\section{Insentif}

Pembayaran insentif yang diberikan kepada karyawan dilakukan atas dasar kinerja yang melebihi standar yang telah ditetapkan perusahaan. Tujuan dari pemberian insentif ini adalah suatu bentuk perusahaan memperlakukan karyawannya sebagai asset yang perlu diberi penghargaan serta menjadikan karyawan tersebut sebagai mitra usaha sehingga karyawan mempunyai rasa memiliki terhadap perusahaan tersebut. Dengan demikian cukup berasalan bagi perusahaan untuk membayar karyawan tersebut dengan insentif sesuai dengan hasil kerjanya.

Menurut T. Hani Handoko (2002:176), menyatakan bahwa pengertian insentif adalah: "Perangsang yang ditawarkan kepada para karyawan untuk melaksanakan kerja sesuai atau lebih tinggi dari standarstandar yang telah ditetapkan".

\section{Motivasi}

Motivasi merupakan motor penggerak yang berada dalam diri manusia, sangat penting untuk terus menerus digerakkan karena dengan motivasi kehidupan manusia akan lebih baik. Berikut pengertian motivasi menurut beberapa ahli. 
Motivasi menurut Veithzal \& Ella Jauvani Sagala (2009:837) adalah "serangkaian sikap dan nilainilai yang mempengaruhi individu untuk mencapai hal yang spesifik sesuai dengan tujuan individu. Sikap dan nilai tersebut merupakan suatu yang invisible yang memberikan kekuatan untuk mendorong individu bertingkah laku dalam mencapai tujuan".

Motivasi menurut Bernard Berendoom dan Gary A. Stainer (dikutip oleh Sedarmayanti, 2009:66) adalah "kondisi mental yang mendorong aktivitas dan memberi energy yang mengarah kepada pencapaian kebutuhan, memberi kepuasan atau menguragi ketidakseimbangan”.

Berdasarkan pengertian motivasi diatas, maka dapat disimpulkan bahwa motivasi adalah "dorongan yang berasal dari diri manusia untuk bangkit mencapai segala tujuan yang dicita-citakan atau diinginkan oleh manusia tersebut".

\section{Kinerja}

Kinerja berasal dari kata job performance atau actual performance yang berarti prestasi kerja atau prestasi sesungguhnya yang dicapai oleh seseorang. Pengertian kinerja (prestasi kerja) adalah hasil kerja secara kualitas dan kuantitas yang dicapai oleh seorang pegawai dalam melaksanakan fungsinya sesuai dengan tanggung jawab yang diberikan kepadanya.

Bernardin dan Russel dalam Ruky (2002) memberikan pengertian atau kinerja sebagai berikut : "performance is defined as the record of outcomes produced on a specified job function or activity during time period". Prestasi atau kinerja adalah catatan tentang hasil-hasil yang diperoleh dari fungsi- fungsi pekerjaan tertentu atau kegiatan selama kurun waktu tertentu.

Menurut Gibson, dkk (2003), job performance adalah hasil dari pekerjaan yang terkait dengan tujuan organisasi, efisiensi dan kinerja kefektifan kinerja lainnya. Sementara menurut Ilyas (1999), kinerja adalah penampilan hasil kerja personil maupun dalam suatu organisasi. Penampilan hasil karya tidak terbatas kepada personil yang memangku jabatan fungsional maupun struktural tetapi juga kepada keseluruhan jajaran personil di dalam organisasi.

\section{METODE PENELITIAN \\ Jenis Penelitian}

Penelitian ini merupakan penelitian tentang manajemen sumberdaya manusia di dalam organisasi. Jenis penelitiannya adalah diskriptif kuantitatif, yakni mengumpulkan data secara kuantitatif dan menggambarkan objek penelitian dengan cara mengemukakan angka-angka secara statitik.

\section{Objek Penelitian}

Penelitian ini akan terfokus pada proses manajemen sumberdaya manusia tentang pengaruh gaya kepemimpinan dan insentif terhadap motivasi serta dampaknya terhadap kinerja Dinas Peternakan dan Perikan Kabupaten Bungo.

\section{Variabel Penelitian}

Variabel penelitian adalah hal-hal yang dapat membedakan atau membawa variasi pada nilai (Sekaran, 2006:67). Penelitian ini menggunakan dua variabel yaitu variabel independen dan variabel dependen.

1. Variabel terikat (Dependent Variable)

Penelitian ini yang menjadi variabel terikat adalah motivasi (Y) dan Kinerja (Z).

2. Variabel bebas (Independent Variable)

Sebagai variabel bebas dalam penelitian ini adalah:
a. Gaya kepemimpinan (X1)
b. Insentif (X2) 


\section{HASIL DAN PEMBAHASAN}

\section{Kondisi eksisting peternak di Kabupaten Bungo}

Berdasarkan data yang di peroleh di Kabupaten Bungo tahun 2017, jumlah petani ternak di Bungo sebanyak 2.803 orang, usia peternak produktif dengan usia 26 tahun sampai 55 tahun sebanyak 2.122 orang atau $75,70 \%$ dan usia tidak produktif antara usia diatas 55 tahun sampai dengan 80 tahun sebanyak 650 orang atau 23,19\%. Peternak yang produktif lebih mampu dalam mengambil keputusan dalam usaha ternak yang dijalankan. Peternak mampu melaksanakan pemeliharaan ternak dan menjadikan permasalahan yang dihadapi sebagai bahan pembelajaran.

\section{Statistika Deskriptif variabel-variabel penelitian} Uji validitas dan realibilitas

Uji validitas digunakan untuk mengetahui seberapa cermat sesuatu instrumen atau item-item dalam mengukur apa yang ingin diukur. Item kuesioner yang tidak valid berarti tidak dapat mengukur apa yang ingin diukur sehingga hasil yang didapat tidak dapat dipercaya, sehingga item yang tidak valid harus dibuang atau diperbaiki (Priyatno, 2013).

Sedangkan, uji reliabilitas digunakan untuk menguji konsistensi alat ukur, apakah hasilnya tetap konsisten atau tidak jika pengukuran diulang. Instrumen kuesioner yang tidak reliabel maka tidak konsisten untuk pengukuran sehingga hasil pengukuran tidak dapat dipercaya (Priyatno, 2013).

Dengan menggunakan alat SPSS uji validitas menggunakan korelasi pearson yaitu mengkorelasikan antara skor tiap item dengan skor total item. Jika nilai signifikansi >0,05 maka item dinyatakan tidak valid, dan jika nilai $<0,05$ maka item dinyatakan valid (Priyatno, 2013). Secara rinci validitas tiap-tiap variabel penelitian diurakan sebagai berikut.

\section{Pengujian validitas gaya kepemimpinan}

Tabel 2

Pengujian validitas gaya kepemimpinan

\begin{tabular}{cccc}
\hline Instrumen & Koefesien korelasi (r hitung) & Siginifikansi & Keterangan \\
\hline P1 & 0,008 & 0,05 & Valid \\
P2 & 0,002 & 0,05 & Valid \\
P3 & 0,000 & 0,05 & Valid \\
P4 & 0,001 & 0,05 & Valid \\
P5 & 0,001 & 0,05 & Valid \\
P6 & 0,008 & 0,05 & Valid \\
P7 & 0,000 & 0,05 & Valid \\
P8 & 0,007 & 0,05 & Valid \\
P9 & 0,005 & 0,05 & Valid \\
\hline
\end{tabular}

Sumber. Data primer yang melalui program SPSS, 2018

\section{Pengujian validitas insentif}

Tabel 3

Pengujian validitas insentif

\begin{tabular}{rccc}
\hline Instrumen & Koefesien korelasi (r hitung) & Siginifikansi & Keterangan \\
\hline P10 & 0,005 & 0,05 & Valid \\
P11 & 0,005 & 0,05 & Valid \\
P13 & 0,003 & 0,05 & Valid \\
P14 & 0,002 & 0,05 & Valid \\
P15 & 0,001 & 0,05 & Valid \\
P16 & 0,002 & 0,05 & Valid \\
P17 & 0,002 & 0,05 & Valid \\
\hline
\end{tabular}

Sumber. Data primer yang melalui program SPSS, 2018 


\section{Pengujian validitas motivasi}

Tabel 4

Pengujian validitas motivasi

\begin{tabular}{rccc}
\hline Instrumen & Koefesien korelasi (r hitung) & Siginifikansi & Keterangan \\
\hline P18 & 0,001 & 0,05 & Valid \\
P19 & 0,002 & 0,05 & Valid \\
P21 & 0,003 & 0,05 & Valid \\
P21 & 0,001 & 0,05 & Valid \\
\hline
\end{tabular}

Sumber. Data primer yang melalui program SPSS, 2018

\section{Pengujian validitas kinerja}

Tabel 5

Pengujian validitas kinerja

\begin{tabular}{cccc}
\hline Instrumen & Koefesien korelasi (r hitung) & Siginifikansi & Keterangan \\
\hline P22 & 0,000 & 0,05 & Valid \\
P23 & 0,005 & 0,05 & Valid \\
P24 & 0,000 & 0,05 & Valid \\
P25 & 0,000 & 0,05 & Valid \\
P26 & 0,000 & 0,05 & Valid \\
P27 & 0,000 & 0,05 & Valid \\
P28 & 0,000 & 0,05 & Valid \\
P29 & 0,000 & 0,05 & Valid \\
P30 & 0,000 & 0,05 & Valid \\
P31 & 0,000 & 0.05 & Valid \\
\hline
\end{tabular}

Sumber. Data primer yang melalui program SPSS, 2018

\section{Hasil uji reliabilitas terhadap variabel gaya kepemimpinan, insentif, motivasi, dan kinerja}

Selain menguji validitas item per item dari variabel penelitian di atas, perlu juga dilakukan pengujian releabilitas untuk setiap variabel sebagai berikut.

Tabel 6

Pengujian reliabilitas terhadap variabel gaya kepemimpinan, insentif, motivasi dan kinerja

\begin{tabular}{lccc}
\hline \multicolumn{1}{c}{ Variabel } & Koefesien variasi (alpha) & R Product Moment (r-tabel) & Keterangan \\
\hline Gaya kepemimpinan & 0,704 & 0,266 & Reliabel \\
Insentif & 0,780 & 0,266 & Reliabel \\
Motivasi & 0,759 & 0,266 & Reliabel \\
Kinerja & 0,792 & 0,266 & Reliabel \\
\hline
\end{tabular}

Sumber. Data primer yang melalui program SPSS, 2018

Dengan koefesien variansi (alpha) untuk setiap variabel lebih besar dari r-tabel sebesar 0,266 yang diperoleh dari responden $(\mathrm{N})$, maka dapat dikatakan bahwa seluruh variabel adalah reliabel dan dapat dijadikan sebagai instrumen pengukuran.

\section{Analisis deskriptif gaya kepemimpinan, insentif, motivasi dan kinerja}

Untuk mengetahui tingkat gaya kepemimpinan, insentif, motivasi dan kinerja dilakukan dengan rentang skala. Hasilnya adalah sebagai berikut.

Tabel 7

Hasil rentang skala masing-masing variabel

\begin{tabular}{ccccc}
\hline No & Variabel & Total skor & Rentang skala & Hasil hipotesis \\
\hline 1 & Gaya kepemimpinan & 1930 & $486-2430$ & Tinggi \\
2 & Insentif & 1438 & $432-2160$ & Sedang \\
3 & Motivasi & 804 & $216-1080$ & Tinggi \\
4 & Kinerja & 2342 & $540-2700$ & Sangat Tinggi \\
\hline
\end{tabular}

Sumber. Data primer yang melalui program SPSS, 2018 
Pada tabel 7 di atas menggambarkan bahwa pemberian gaya kepemimpinan (X1) pada Dinas Peternakan dan Perikanan Kabupaten Bungo berada pada angka 1930 dengan kategori tinggi. Insentif (X2) berada pada angka 1438 dengan kategori sedang, Motivasi kerja (Y) berada pada angka 804 dengan kategori tinggi dan kinerja (Z) berada pada angka 2342 dengan kategori sangat tinggi.

\section{Pengaruh gaya kepemimpinan, insentif secara bersama-sama terhadap kinerja melalui motivasi}

Untuk menjawab tujuan ke sembilan, beradasarkan perolehan nilai pada masing-masing sub struktur koefesien jalur yang telah diuraikan dan dijelaskan baik secara langsung maupun tidak langsung, serta pengaruh total antara masing- masing variabel bebas, seperti gaya kepemimpinan (X1), dan insentif (X2) melalui variabel intervening motivasi (Y) terhadap variabel terikat kinerja (Z), apabila sub struktur IV tersebut dibuat menjadi satu kesatuan utuh dari analisis koefesien jalur (path analiysis) yang digunakan dalam penelitian ini dapat dilihat pada gambar sebagai berikut.

Untuk mendapatkan berapa besar pengaruh Pengaruh variabel gaya kepemimpinan (X1) dan variabel insentif (X2) langsung dan tidak langsung secara bersama-sama terhadap kinerja (Z) melalui motivasi (Y).

- Pengaruh langsung X1 dan X2 terhadap Z melalui Y adalah:

$=($ Pzx 1$)($ Pyx 1$)($ Pzy $)+($ Pzx 2$)($ Pyx 2$)($ Pzy $)$

$=(0,375)(-0,434)(-0,637)+(-0,135)(-0,073)(-0,637)$

$=1,039 \%+0,062 \%$

$=1,101 \%$

- Pengaruh tidak langsung X1 dan X2 terhadap Z melalui $\mathrm{Y}$

$=(\mathrm{Pzx} 1)(\mathrm{Pyx} 1)(\mathrm{rx} 1 \mathrm{x} 2)(\mathrm{Pyx} 2)(\mathrm{Pzy})+(\mathrm{Pzx} 2)(\mathrm{Pyx} 2)(\mathrm{rx} 1 \mathrm{x} 2)(\mathrm{Pyx} 1)(\mathrm{Pzy})$

$=(0,375)(-0,435)(-0,481)(-0,073)(-0,637)+(-0,135)(-0,073)(-0,481)(-0,434)(-0,637)$

$=0,364 \%+0,013 \%=0,377 \%$

- Total pengaruh X1 dan X2 terhadap Z melalui Y

$=$ Pengaruh langsung + pengaruh tidak langsung

$=1,101 \%+0,377 \%$

$=1,478 \%$

Berdasarkan perrhitungan di atas dapat disimpulkan bahwa pengaruh langsung gaya kepemimpinan dan insentif secara berasama-sama melalui motivasi terhadap kinerja sebesar $1,101 \%$, pengaruh tidak langsungnya sebesar $0,377 \%$ dan total pengaruhnya adalah $1,478 \%$. Dengan demikian, secara bersamasama variabel gaya kepemimpinan dan insentif melalui motivasi memberikan sumbangan terhadap kinerja pegawai Dinas Peternakan dan Perikanan Kabupaten Bungo.

\section{Pembahasan}

\section{Gaya kepemimpinan}

Variabel gaya kepemimpinan pada penelitian ini diukur melalui sembilan pernyataan yang mempresentasikan indikator-indikator dari variabel gaya kepemimpinan, secara keseluruhan, ke sembilan pernyataan dari variabel gaya kepemimpinan responden menjawab dengan nilai 1930 berada pada kategori tingi, angka ini merupakan jumlah yang tinggi terhadap perhitungan gaya kepemimpinan pada Dinas Peternakan dan Perikanan Kabupaten Bungo, artinya pelaksanaan gaya kepemimpinan pada Dinas Peternakan dan Perikanan Kabupaten Bungo baik.

\section{Insentif}

Variabel insentif diukur dengan delapan pernyataan yang dimulai dengan pernyataan ke sepuluh hingga pernyataan ke 17, pernyataan ini mempersentasekan dari variabel insentif, dengan rincian jawaban responden sebagai berikut.

Dari hasil perhitungan jawaban yang didapati, bahwa variabel insentif memperoleh angka 1438 dengan kategori sedang, artinya pelaksanaan insentif pada Dinas Peternakan dan Perikanan Kabupaten Bungo baik. 


\section{Motivasi}

Variabel penelitian motivasi diukur dengan empat indikator variable motivasi, dari hasil perhitungan diperoleh angka berada 804, dengan kategori tinggi. Ini artinya bahwa motivasi kerja yang dilaksanakan di Dinas Peternakan dan Perikanan Kabupaten Bungo baik.

\section{Analisis variabel kinerja}

Dari indikator-indikator variabel kinerja yang diteliti, diperoleh hitungan bahwa kinerja pegawai Dinas Peternakan dan Perikanan Kabupaten Bungo berada pada angka 2342 dengan kategori sangat tinggi, semua kuesioner memperoleh angka yang sangat tinggi. Ini menunjukkan bahwa kinerja Dinas Peternakan dan Perikanan Kabupaten Bungo sangat baik.

\section{SIMPULAN}

Berdasarkan dari hasil penelitian yang diuraikan di atas, maka dapat dibuat kesimpulan untuk menjawab rumuasan masalah yaitu sebagai berikut.

1. Gaya kepemimpinan, insentif, motivasi dan kinerja Dinas Peternakan dan Perikanan Kabupaten Bungo adalah baik, untuk gaya kepemimpinan dengan skor 1930, untuk insentif dengan skor 1438, untuk motivasi dengan skor 804 dan kinerja berada pada skor 2342 yang berada pada kategori sangat tinggi.

2. Gaya kepemimpinan terhadap motivasi Dinas Peternakan dan Perikanan Kabupaten Bungo berpengaruh secara langsung maupun tidak langsung dengan nilai 20,35\%.

3. Pengaruh insentif terhadap motivasi Dinas Peternakan dan Perikanan Kabupaten Bungo berpengaruh secara langsung maupun tidak langsung dengan nilai $0,205 \%$.

4. Pengaruh gaya kepemimpinan dan insentif terhadap motivasi Dinas Peternakan dan Perikanan Kabupaten Bungo berpengaruh secara langsung maupun tidak langsung dengan nilai 2,86\%.

5. Terdapat pengaruh gaya kepemimpinan terhadap kinerja Dinas Peternakan dan Perikanan Kabupaten Bungo dengan nilai $1,43 \%$.

6. Terdapat pengaruh insentif terhadap kinerja Dinas Peternakan dan Perikanan Kabupaten Bungo dengan nilai berada pada $2,065 \%$.

7. Pengaruh gaya kepemimpinan dan insentif terhadap kinerja Dinas Peternakan dan Perikanan Kabupaten Bungo memiliki pengaruh dengan nilai 2,471\%.

8. Pengaruh motivasi terhadap kinerja Dinas Peternakan dan Perikanan Kabupaten Bungo berada pada angka $4,057 \%$

9. Pengaruh gaya kepemimpinan dan insentif melalui motivasi terhadap kinerja Dinas Peternakan dan Perikanan Kabupaten Bungo memiliki pengaruh dengan nilai 1,478\%.

\section{DAFTAR PUSTAKA}

Akdon H, Wahyudi, 2006, Menajemen Konflik dalam Organisasi, Bandung: Alfabeta, Anggota Ikatan Penerbit Indonesia (IKAPI).

Ardana, I Komang dkk, 2012, Manajemen Sumber Daya Manusia, Graha Ilmu, Yogyakarta.

As'ad, 2004, Psikoligi Industri, Galia Indonesia, Yogyakarta

Bernardin, H. John, \& Russel, E.A, 1993. Human Resources Management, An Experiental Approach, Mc Graw Hill International Editions, Mac Graw Hill Book Co. Singapore.

Dessler, Gary, 2000, Manajemen Sumber Daya Manusia, Edisi Terjemahan, Penerbit PT. Prenhallindo, Jakarta.

, 2010, Manajemen Sumber Daya Manusia. Jakarta. Indeks.

Echols, John M., \& Shadly, Hasan, 2007, Kamus Inggeris Indonesia, Jakarta, Gramedia.

Gibson, dkk. 2003. Organisasi: Perilaku, Struktur, Proses, Edisi Kesepuluh, Jilid 1, Alih Bahasa Djarkasih, Erlangga, Jakarta.

Griffin, Ricky W, 2007, Principles of Management, Houghton Miffin Company, USA

Hamzah. B. Uno, 2007, Profesi Kependidikan, Bumi Aksara, Jakarta

Hasibuan, Malayu. S.P. 2003. Organisasi dan Motivasi Dasar Peningkatan Produktivitas, PT. Bumi Aksara, Jakarta 
2006, Manajemen Sumber Daya manusia, Edisi Revisi, Bumi Aksara, Jakarta

Ilyas, Y., 1999, Kinerja: Teori Penilaian dan Penelitian, Jakarta: FKM UI. IQ, Jakarta: PT Gramedia Pustaka Utama

Irawan, Handi, 2002. 10 Prinsip Kepuasan Pelanggan, PT. Elex Media Komputindo,. Jakarta.

Kerlinger, Fred N, 2002, Asas-Asas Penelitian Behavioral, Yogyakarta: Gajah Mada University Press

Koencoro, Galih Dwi. 2013. Pengaruh Reward Dan Punishment Terhadap Kinerja. Skripsi. Universitas Brawijaya.

Labolo, Muhadam. 2006. Memahami Ilmu Pemerintahan, Jakarta: Raja Grafindo

Mangkunegara, AP. 2000. Manajemen Sumber Daya Manusia, Cetakan Pertama. Bandung : Rosada.

McCloy, A. R., Campbell, P. J., \& Cudeck, R., (1994), A Confirmatory Test A Model of Performance Determinants, Journal of Applied Psychology, Vol. 79, No.4, 493-505.

Moekijat. 2008, Prinsip-Prinsip Management Suatu Tanya Jawab, cetakan ke lima, Alumni, Bandung.

Nawawi, Hadari. 2005. Manajemen Sumber Daya Manusia untuk Bisnis yang Kompetitif. Yogyakarta: Gadjah Mada University Press.

Ngalim Purwanto, 2006, Administrasi dan Supervisi Pendidikan, Edisi Revisi, Remaja Rosda Karya, Bandung.

Nitisemito, Alex S, 1996, Manajemen Personalia, Ghalia Indonesia, Bandung.

Pahlevi, Resa Nur. 2012. Pengaruh Penerapan Reward dan Punishment Terhadap Kinerja Pegawai Negeri Sipil di Badan Kepegawaian dan Diklat Kota Cilegon. Skripsi Sarjana pada Universitas Sultan Ageng Tirtayasa, Serang (online).

Priyatno, 2013, Belajar praktis analisis parametrik dan non parametrik dengan SPSS \& prediksi pertanyaan pendadaran skripsi dan tesis, Yogyakarta: Gava Media.

Panggabean, Mutiara.S, 2002, Manajemen Sumber Daya Manusia, Ghalia Indonesia, Jakarta

Robbins, Stephen P., 1996. Perilaku Organisasi Jilid II, Alih Bahasa Hadayana Pujaatmaka, Jakarta, Prenhalindo.

Robbins, Stephen P., and David A. DeCenzo, 1999, Human Resource Management 6th. USA: John Wiley \& Sons, Inc. 2006. Perilaku Organisasi, PT Indeks, Kelompok Gramedia, Jakarta.

Ruky, Achmad S, 2002, Sistem Manajemen Kinerja, Jakarta.Gramedia, Pustaka Utama.

Sekaran, Uma.(2006). Metodologi Penelitian untuk Bisnis. Jilid 1. Edisi 4.Salemba Empat, Jakarta.

Sedarmayanti. (2001). Sumber Daya Manusia dan Produktivitas Kerja. Mandar Maju, Bandung.

Simanjuntak, Payaman J, 2011, Manajemen dan Evaluasi Kinerja, Fakultas Ekonomi UI, Jakarta

Sinungan, Muchdarsyah, 2005, Produktivitas: Apa dan Bagaimana, Edisi Kedua. Bumi Aksara.

Strong, C.F. 1970, Modern Political Constitutions: An Introduction to the Comparative Study of Their History and Form. London: Sedgwick \& Jackson Limited, x, 389 pp.

Sugiyono, 2001, Metode Penelitian Administrasi, Alfabeta, Bandung , 2014, Metode Penelitian Kombinasi (Mixied Methods) Alfabeta, Bandung

Suwarto, 2011. Perilaku Keorganisasian: Universitas Atma Jaya Yogyakarta

Robbins, Stephen P., and David A. DeCenzo, 2003, Human Resource Management 6th. USA: John Wiley \& Sons, Inc.

Siagian, Sondang P, 2006, Teori Motivasi dan Aplikasinya, Rineka Cipta, Jakarta

Thoha, Miftah, 2003, Kepemimpinan Dalam Manajemen, Jakarta: PT. Raja Grafindo Persada

Tohardi, 2002, Pemahaman Praktis Manajemen Sumber Daya Manusia, Universitas Tanjung Pura, Mandar Maju, Bandung.

Veithzal, Rivai. (2005). Manajemen Sumber Daya Manusia. Jakarta: Raja Grafindo Persada.

Wahjosumidjo, 2002, Kepemimpinan dan Motivasi, Ghalia Indonesia, Jakarta

Wibowo, 2007, Manajemen Kinerja, Rajagrafindo Persada, Jakarta 